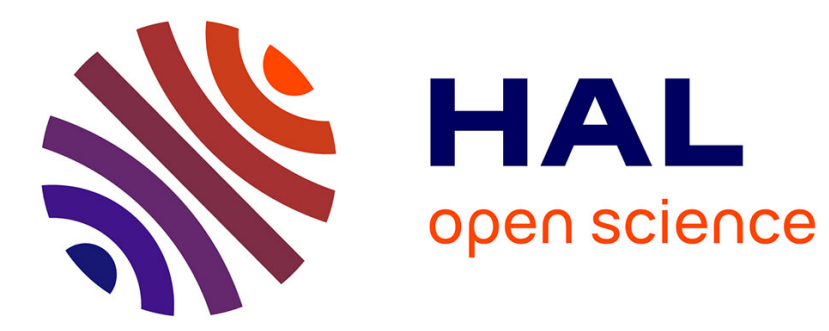

\title{
Relaxation Phenomena of MgZn Ferrites
}

\author{
T. Murase, K. Igarashi, J. Sawai, T. Nomura
}

\section{To cite this version:}

T. Murase, K. Igarashi, J. Sawai, T. Nomura. Relaxation Phenomena of MgZn Ferrites. Journal de Physique IV Proceedings, 1997, 07 (C1), pp.C1-99-C1-100. 10.1051/jp4:1997128 . jpa-00254992

\section{HAL Id: jpa-00254992 https://hal.science/jpa-00254992}

Submitted on 1 Jan 1997

HAL is a multi-disciplinary open access archive for the deposit and dissemination of scientific research documents, whether they are published or not. The documents may come from teaching and research institutions in France or abroad, or from public or private research centers.
L'archive ouverte pluridisciplinaire HAL, est destinée au dépôt et à la diffusion de documents scientifiques de niveau recherche, publiés ou non, émanant des établissements d'enseignement et de recherche français ou étrangers, des laboratoires publics ou privés. 


\title{
Relaxation Phenomena of MgZn Ferrites
}

\author{
T. Murase, K. Igarashi, J. Sawai and T. Nomura \\ 570-2 Aza-Matsugashita, Minami-Hatori, narita-shi, Chiba-ken 286, Japan
}

\begin{abstract}
The decrease of initial permeability $\left(\mu_{\mathrm{i}}\right)$ with increasing frequency is enhanced by $\mathrm{CuO}$ addition to $\mathrm{MgZn}$ ferrite. The gradual deterioration of $\mu$. with frequency is due to a relaxation phenomenon. By measuring the temperature dependence of tan $\delta$, the activation energy of the relaxation was calculated as approximately $0.43 \mathrm{eV}$. From the results of time disaccommodation, the change in permeability for $\mathrm{MgCuZn}$ ferrite was found to be larger than that of $\mathrm{MgZn}$ ferrite. Futhermore, the deterioration of $\mu_{i}$ with time for both ferrites continued for more than 500 hours.
\end{abstract}

\section{INTRODUCTION}

Soft ferrites are widely used in electronic equipments, and recently, the demand for highly inductive materials has increased so as to lower prices. $\mathrm{MgZn}$ ferrite is used in large quantities because it is highly cost effective. In general, copper and manganese oxides are added to $\mathrm{MgZn}$ ferrites in order to achieve high quality. CuO addition is especially effective in lowering the sintering temperature and core loss at high frequency. It has, however, a deleterious effect on the stability of initial permeability $\left(\mu_{\mathrm{i}}\right)$. CuO addition also causes the deterioration of $\mu_{\mathrm{i}}$ with increasing frequency. This gradual deterioration of $\mu_{i}$ with frequency is a relaxation phenomenon. The relaxation is presumed to be the delay of the domain wall motion with respect to change in the external magnetic field. It is inferred that the delay of the domain wall motion may be caused by electron migration, cation migration, impurities or by defects. The purpose of this paper is to focus on the relaxation phenomenona in $\mathrm{MgZn}$ and $\mathrm{MgCuZn}$ ferrites, with special reference to the chemical composition and microstructure.

\section{EXPERIMENTAL}

Ferrite powders in the $\mathrm{MgO}-\mathrm{CuO}-\mathrm{ZnO}-\mathrm{Fe}_{2} \mathrm{O}_{3}$ system were prepared by conventional powder processes. The starting raw materials are commercial grade powders, $\mathrm{Mg}(\mathrm{OH})$, $\mathrm{CuO}, \mathrm{ZnO}, \mathrm{Fe}_{2} \mathrm{O}_{3}$. The above raw materials were weighed and then mixed in a ballmill for 16 hours. Afterwards, the mixed powders were dried, calcined at $900^{\circ} \mathrm{C}$ for 3 hours and re-milled using a wet -method for 16 hours. The average particle size of the ferrite powders was about $1.5 \mu \mathrm{m}$. Then, the powders were granulated using $0.6 \mathrm{wt} \%$ of PVA and pressed into T-10 toroids and disks ( $\phi=12 \mathrm{~mm}, \mathrm{~d}=1.8 \mathrm{~mm}$ ). The green bodies were fired between 1100 and $1400^{\circ} \mathrm{C}$ in air, with heating and cooling rate of $300^{\circ} \mathrm{C}$ per hour in air. Afterwards, the toroids were wound with 20 turns of $\mathrm{Cu}$ wire and the disks were electroded using In-Ga or Pt on both faces. The electromagnetic properties were measured using LCR meters (HP 4192A, HP E2377A, YHP 4194A and YHP 4329A). Microstructures were observed using optical microscopy (OM) and transmission electron microscopy (TEM).

\section{RESULTS AND DISCUSSION}

The effect of $\mathrm{CuO}$ addition on the frequency dependence of $\mu_{\mathrm{i}}$ is shown in Fig. 1 .

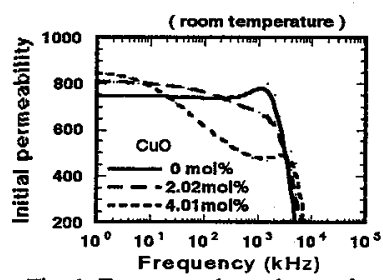

Fig. 1 Frequency dependence of initial permeability. $\left(\mathrm{ZnO}=21.2, \mathrm{Fe}_{2} \mathrm{O}_{3}=49.4 \mathrm{~mol} \%\right)$

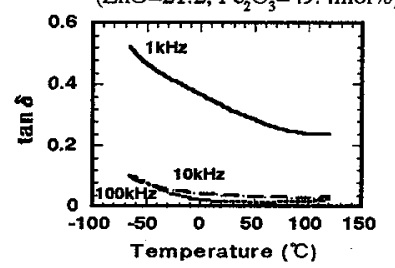

Fig. 2 Temperature dependence of $\tan \delta$ for $\mathrm{MgZn}$ ferrite. $(\mathrm{MgO}=29.2, \mathrm{ZnO}=21.3$, $\mathrm{CuO}=0, \mathrm{Fe}_{2} \mathrm{O}_{3}=49.5 \mathrm{~mol} \%$ )

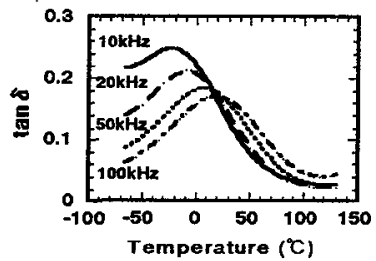

Fig. 3 Temperature dependence of $\tan \delta$ for $\mathrm{MgCuZn}$ ferrite. $(\mathrm{MgO}=25.2, \mathrm{ZnO}=21.3$, $\mathrm{CuO}=4.0, \mathrm{Fe}_{2} \mathrm{O}_{3}=49.5 \mathrm{~mol} \%$ ) 


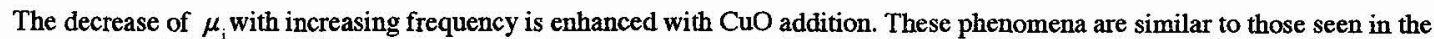
case of $\mathrm{Mn}_{2} \mathrm{O}_{3}$ addition[1, 2]. The temperature dependence of $\tan \delta$ for $\mathrm{MgZn}$ and $\mathrm{MgCuZn}$ ferrites are shown in Fig. 2 and 3 . Peaks for the $\mathrm{MgZn}$ ferrite are not observed in the temperature range measured but may exist at lower temperatures than $-70^{\circ} \mathrm{C}$. On the other hand, peaks for the $\mathrm{MgCuZn}$ ferrite appear within the tested temperature range. The peaks shift to a higher temperature region and the values decrease with increasing frequency. In general, $\tan \delta$ is expressed by the Curie-Weiss law in equation (1). The frequency is expressed by equation (2) when $\tan \delta$ is maximum. On examining the relationship between the temperature at the $\tan \delta$ peak in Fig. 3 and the relaxation time $(\tau)$, good agreement was found with the Arrhenius equation (3). $\tan \delta=\chi_{\mathrm{r}} \omega \tau /\left[\left(1+\chi_{\mathrm{r}}\right)+\omega^{2} \tau^{2}\right] \quad\left(\chi_{\mathrm{r}}:\right.$ relative magnetic susceptibility $) \cdots(1)$ $\omega \tau=1$

$\tau=\tau_{0} \exp (\mathrm{Q} / \mathrm{kT}) \quad\left(\tau_{0}:\right.$ frequency factor, $\mathrm{k}:$ Boltzmann constant $) \cdots(3)$ Consequently, the activation energy of the relaxation for the $\mathrm{MgCuZn}$ ferrite is calculated as about $0.43 \mathrm{eV}$.This value is similar to that found for $\mathrm{Mn}_{2} \mathrm{O}_{3}$ addition to $\mathrm{MgZn}$ ferrite. The activation energy for electron transfer in ferrites, i.e. for $\mathrm{Fe}^{2+} \Leftrightarrow \mathrm{Fe}^{3+}$, is known to be about $0.1 \mathrm{eV}[3]$, while that for carbon migration in Armco iron is about $1.0 \mathrm{eV}$ [4]. As the value measured here falls between the two, it is reasonable to infer that it is also due to cation migration. Usually, the diffusion in the crystal occurs via point defects. It is suggested that the relaxation in the $\mathrm{MgCuZn}$ ferrite may be caused by the delay of domain wall motion due to point defects.

The characterization technique for defects in semiconductors $[5,6]$, involving measurement of electric conductivity dependence on the oxygen pressure $\left(\mathrm{Po}_{2}\right)$, was used in the present study on the $\mathrm{MgZn}$ and $\mathrm{MgCuZn}$ ferrites (Fig. 4). It was expected to recognize that the $\mathrm{MgCuZn}$ ferrite differed from $\mathrm{MgZn}$ ferrite in the type, concentration and arrangement of defects. In our experiment the specimens were kept at a given $\mathrm{Po}_{2}$ at $700^{\circ} \mathrm{C}$ and were measured after 2 hours. Each of them was measured from high- $\mathrm{Po}_{2}$ to low- $\mathrm{Po}_{2}$ (the solid lines), and then from low- $\mathrm{Po}_{2}$ to high- $\mathrm{Po}_{2}$ (the dotted lines) using the same specimen in each case. In both $\mathrm{MgZn}$ and $\mathrm{MgCuZn}$ ferrites the values from the first measurement are not in agreement with those from the second measurement. It is supposed that the specimens formed different phases in the strongly reducing atmosphere and did not equilibrate sufficiently in 2 hours from low- $\mathrm{Po}_{2}$ to high-Po - At present, variations of time and temperature are being investigated to solve this problem.

In order to study the effect of microstructures on relaxation phenomena, OM and TEM were performed. Photo. 1 shows the microstructures of polished and hydrofluoric acidetched surfaces of $\mathrm{MgZn}$ and $\mathrm{MgCuZn}$ ferrites sintered at $1250^{\circ} \mathrm{C}$. It seems that $\mathrm{CuO}$ addition accelerates grain growth. The large grains of $\mathrm{MgCuZn}$ ferrite contain pores and

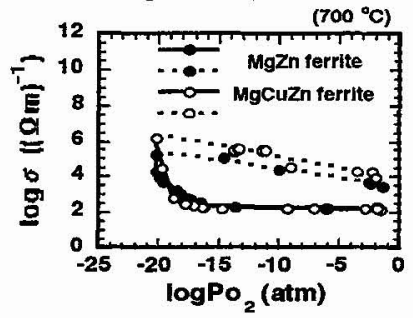

Fig. 4 Oxygen pressure dependence of conductivity.

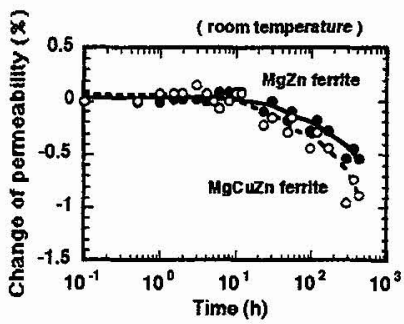

Fig. 5 The disaccommodation of the $\mathrm{MgZn}$ ferrite. etch pits. It is supposed that grain growth and pores are related to the decrease of $\mu_{\mathrm{i}}$ with frequency. Furthermore, it is believed that etch pits are initiated by defects. In order to find lattice defects, the nanostructure of these samples was observed using TEM. It was expected that the lattice fringes would be distorted by defects. However, no distortion was witnessed (Photo. 2).

The electric conductivity investigation and the TEM observation did not adequate characterize the defects for $\mathrm{MgZn}$ and $\mathrm{MgCuZn}$ ferrites. However, results of time disaccommodation of magnetic permeability for these ferrites confirm differences in the defect structures. The time dependence of the change of permeability is shown in Fig. 5 . The change in permeability for $\mathrm{MgCuZn}$ ferrite is larger than that in $\mathrm{MgZn}$ ferrite. It is thought that the difference is due to the concentration of defects. Futhermore, from this figure it can be seen that the deterioration of $\mu_{i}$ for both ferrites continues for 500 hours or more. It is expected that the relaxation time for our specimens is longer than that for $\mathrm{MgZn}$ ferrite, as observed by Ohta[7].

\section{CONCLUSION}

In this study, the effect of $\mathrm{CuO}$ addition on relaxation in $\mathrm{MgZn}$ ferrite was investigated. The changes of permeability with frequency and time are enhanced by $\mathrm{CuO}$ addition to $\mathrm{MgZn}$ ferrite. By examining the relationship between the temperature and the relaxation time, the activation energy for $\mathrm{MgCuZn}$ ferrite was found to be about $0.43 \mathrm{eV}$. Furthermore, the relaxation time on disaccommodation for both compositions was longer than 500 hours.

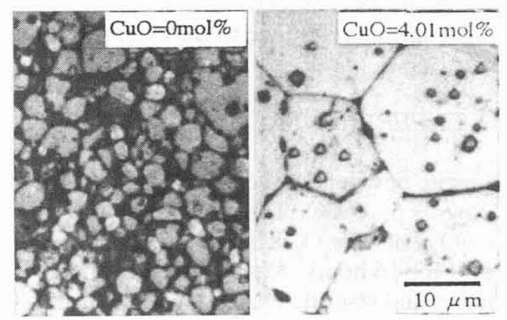

\section{Reference}

Photo. 1 Microstructures of the $\mathrm{MgZn}$ ferrites.

[1] K. Igarashi, T. Murase and T. Nomura, Powder and Powder Metallurgy, 42 (1995) 22.

[2] K. Igarashi, T. Murase and T. Nomura, Materials Engineering for Resources of Japan, 8 (1995) 61.

[3] Y.Tawara, J. Phys. Soc. Japan, 17 (1962) 1711.

[4] Y. Tomono, J. Phys. Soc. Japan, 7 (1952) 174.

[5] F. A. Kroger and H. J. Vink, "Solid State Physics", 3, F. Seitz, D. Turnbull(eds.), (1956) 313.

[6] N. G. Eror and U. Balachandran, Journal of Solid State Chemistry, 42 (1982) 227 241.

[7] K. Ohta, J. Phys. Soc. Japan, 16 (1961) 250.

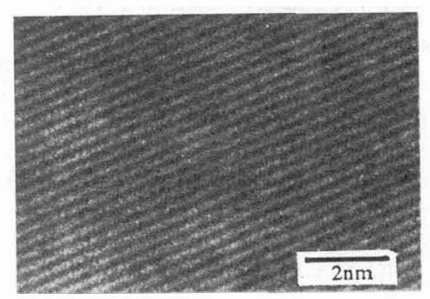

Photo. 2 TEM image of $\mathrm{MgCuZn}$ ferrite. 